\title{
L-Type Cardiac Calcium Channels in Doxorubicin Cardiomyopathy in Rats Morphological, Biochemical, and Functional Correlations
}

\author{
Edmund C. Keung, ${ }^{*}$ Lawrence Toll, ${ }^{*}$ Marie Ellis, ${ }^{*}$ and Richard A. Jensen* \\ *Cardiology Section, Veterans Affairs Medical Center and Department of Medicine, University of California, San Francisco, 94121 ; \\ and ${ }^{\ddagger}$ Life Sciences, SRI, International, Menlo Park 94025 , California
}

\begin{abstract}
Doxorubicin (DXR) is an effective antitumor agent in a wide spectrum of neoplasms. Chronic treatment is associated with cardiomyopathy and characteristic myocardial ultrastructural changes, which include swelling of the $t$ tubules. Accordingly, we investigated excitation-contraction coupling in cardiomyopathic rat heart resulting from chronic DXR treatment. Using the whole-cell patch clamp technique, we studied the L-type calcium channel in single cells enzymatically isolated from normal (CTRL) and DXR rat hearts. Despite similar cell dimensions, the total membrane capacitance was significantly smaller in the DXR cells $(138 \pm 9 \mathrm{pF})$ than in the CTRL cells $(169 \pm 11$ pF) (mean \pm SEM, $n=9, P<0.05)$. The mean current and the current density-voltage relationships of the CTRL and the DXR cells were significantly different $(n=9, P<0.001)$ with the maximal peak L-type calcium current $\left(I_{C_{a}}\right)$ density increased from $6.4 \pm 0.9$ in CTRL cells to $10.5 \pm 2.4 \mu \mathrm{A} / \mathrm{cm}^{2}$ in the DXR cells $(P<0.05)$. There was no shift either in the currentvoltage relationship or the steady-state inactivation curve in the two cell groups. However, the fast time constant of inactivation was increased at a membrane voltage of -10 to $10 \mathrm{mV}$. Calcium channel antagonist equilibrium binding assays using $\left[{ }^{3} \mathrm{H}\right]-$ PN200-110 revealed no difference in the maximal receptor binding capacity (CTRL, 194 \pm 27 and DXR $211 \pm 24 \mathrm{fmol} / \mathrm{mg}$ protein; $P>0.05, n=6$ ) and in receptor affinity (CTRL, $0.15 \pm 0.05$ and DXR $0.13 \pm 0.03 \mathrm{nM} ; P<0.05)$. These data suggest that a decrease in effective capacitance might be associated with t-tubular damage. Despite this decrease, $I_{C a}$ was increased in the DXR cells. Such an increase may result from an alteration in the properties of the calcium channels and/or recruitment of "hibernating" channels in the remaining surface and t-tubular membranes. (J. Clin. Invest. 1991. 87:21082113.) Key words: calcium current • cell capacitance • doxorubicin $\bullet$ cardiomyopathy $\bullet t$ tubule
\end{abstract}

\section{Introduction}

Doxorubicin (DXR) ${ }^{1}$, an anthracycline antibiotic, has been used either as single drug treatment or as part of combination chemotherapy in the treatment of lymphomas, leukemias, sar-

Address correspondence to Dr. Edmund C. Keung, Cardiology (111C), Veterans Affairs Medical Center, 4150 Clement Street, San Francisco, CA 94121.

Received for publication 14 February 1990 and in revised form 29 January 1991.

1. Abbreviations used in this paper: ANOVA, analysis of variance; $B_{\max }$, maximal binding capacity; $c_{\mathrm{m}}$, cell capacitance; CTRL, control; DXR, doxorubicin; $I_{\mathrm{Ca}}, \mathrm{L}$-type calcium current.

The Journal of Clinical Investigation, Inc

Volume 87, June 1991, 2108-2113 comas, ovarian, and breast cancers (1). One of the major complications of prolonged DXR treatment is congestive heart failure resulting from degenerative cardiomyopathy. Once it occurs, severe congestive heart failure is refractory to therapy. While the mechanism of DXR cardiotoxicity is not clear, studies in human and animal models of DXR cardiomyopathy have shown extensive functional, morphological, and biochemical abnormalities (2). Recently, a direct effect of DXR on the calcium release channel from cardiac (3) and skeletal (4) sarcoplasmic reticulum has been demonstrated. Left ventricular papillary muscles from DXR-treated rats showed a decrease in the maximum rate of tension development, prolonged time to peak tension and tension duration. The inotropic and lusitropic effects in response to isoproterenol were also reduced (5). Jensen and co-workers demonstrated that the electrocardiogram of DXR-treated rats is characterized by increased QRS and $\mathrm{Q}_{\alpha} \mathrm{T}$ intervals and a marked prolongation of the transmembrane action potential (6). In rats and humans DXR-induced myocardial lesions are characterized by myofibrillar loss, marked cytoplasmic vacuolization, swelling of the t-tubular system, mitochondria, and the sarcoplasmic reticulum (2, 7). The aforementioned ultrastructural, mechanical, and electrophysiologic changes strongly suggest a defective excitationcontraction coupling process in DXR cardiomyopathy. Furthermore, one of us (7) has published electron micrographs showing t-tubular damage in myocardium from chronic DXR cardiomyopathic rats. Such damage may result in changes in the total electrically effective cell membrane area (t-tubular and surface sarcolemmal areas) measured as membrane capacitance. Accordingly, using enzymatically isolated single cardiomyocytes, we sought to characterize and establish some functional correlation between cell capacitance $\left(c_{\mathrm{m}}\right)$ and the L-type calcium current $\left(I_{\mathrm{Ca}}\right)$ and the number of putative calcium channels as estimated by calcium antagonist receptor binding sites in chronic DXR cardiomyopathic rats.

\section{Methods}

DXR cardiomyopathy model. Experimental procedures were approved by SRI, International and San Francisco Veterans Affairs Medical Center Committees on Animal Research. Female Sprague-Dawley rats weighing 180-250 g were used in the study. DXR cardiomyopathy was induced as previously described (5). In brief, DXR, obtained as a gift from Adria Laboratories, Inc., Columbus, $\mathrm{OH}$, was administered intraperitoneally at a dose of $2.5 \mathrm{mg} / \mathrm{kg}$ once weekly for $10 \mathrm{wk}$. Agematched rats given intraperitoneal injections of saline were used as controls (CTRL). Rats were used for experiments at the end of the treatment period when the DXR treated rats developed ascites, hepatomegaly, subcutaneous edema, and pericardial effusion.

Cell isolation. Single ventricular cells were isolated by a modification of the procedure used by Silver et al. (8). The animals were anesthetized with pentobarbital intraperitoneally, and the heart rapidly excised and attached to a Langendorf perfusion apparatus. The heart was then 
retrogradely perfused for 2-3 min with nominally calcium-free KrebsHenseleit solution equilibrated with $95 \% \mathrm{O}_{2}$ and $5 \% \mathrm{CO}_{2}$ at $35^{\circ} \mathrm{C}$. Enzymatic digestion was achieved by perfusing the heart with the calcium-free Krebs-Henseleit solution containing $1.5 \mathrm{mg} / \mathrm{ml} \mathrm{(125} \mathrm{U/mg}$ dry wt) collagenase (Type II, Worthington Biochemical Corp., Freehold, NJ) at a constant rate of $1-2 \mathrm{ml} / \mathrm{min}$ with a peristaltic pump for $30 \mathrm{~min}$. The ventricles were then separated from the atria and cut into small pieces and further digested with fresh enzyme solution plus $1 \%$ BSA for $10 \mathrm{~min}$ in an atmosphere of $95 \% \mathrm{O}_{2}$ and $5 \% \mathrm{CO}_{2}$ at $35^{\circ} \mathrm{C}$. Cells were filtered, washed twice with "KB medium" (9), and preincubated in this medium for $1 \mathrm{~h}$. Finally, the cells were suspended in MEM culture medium containing $3 \%$ horse serum and stored in a cell incubator for $30 \mathrm{~min}-1 \mathrm{~h}$ before experiments. The yield of rod-shaped quiescent cells at a calcium concentration of $1.8 \mathrm{mM}$ was $40-60 \%$ for the control rats and $25-50 \%$ for DXR-treated rats. $I_{\mathrm{Ca}}$ was robust with no apparent rundown observed during 20-30 min after establishing a whole-cell configuration.

Voltage clamp experiments. Voltage clamp experiments were performed in the whole-cell configuration using the single-pipette patchclamp method (10) and an Axopatch-1B patch clamp system (Axon Instruments, Inc., Foster City, CA). Pipettes were fabricated from 1.8 mm OD Microstar glass tubing (Radnoti Glass Technology, Inc., Monrovia, CA) using a microprocessor-based patch pipette puller (PC84; Sutter Instrument Co., San Rafael, CA). The pipettes had an internal tip diameter of 2-2.5 $\mu \mathrm{m}$ after slight fire-polishing and a resistance of 0.8-2.0 M $\Omega$ after back-filling with the experimental internal solution. 1-4 G $\Omega$ seals between the pipette tip and the cell membrane were achieved in an external solution containing (in millimolars): $\mathrm{NaCl} 137$, $\mathrm{KCl} 5.4, \mathrm{MgCl}_{2} 1.0, \mathrm{CaCl}_{2} 1.8$, Hepes 10 , glucose 10 at $\mathrm{pH}=7.4$ (titrated with $\mathrm{NaOH}$ ). The internal pipette solution contained (in millimolars): $\mathrm{CsCl} 140, \mathrm{MgCl}_{2} 2$, Hepes $10, \mathrm{CaCl}_{2} 1$, EGTA $11, \mathrm{~K}_{2} \mathrm{ATP} 5$ at $\mathrm{pH}=7.2$ (titrated with $\mathrm{CsOH}$ ). The fast inward sodium current (11) and T-type calcium channel, if present, were inactivated by holding the membrane potential at $-40 \mathrm{mV}$. K currents were eliminated by inclusion of $\mathrm{Cs}^{+}$in the pipette solution and by replacing the above external solution after the whole-cell configuration was achieved with a $\mathrm{K}^{+}$-free solution that contained (in millimolars): Tris- $\mathrm{HCl} 137, \mathrm{NaOH} \mathrm{20,} \mathrm{CsCl}$ $5.4, \mathrm{MgCl}_{2} 1.0, \mathrm{CaCl}_{2} 1.8$, Hepes 10 , glucose 10 at $\mathrm{pH}=7.4(12-14)$. All experiments were performed at an ambient temperature of $22-25^{\circ} \mathrm{C}$.

Data acquisition and analysis. During the experiments, voltage and current data were displayed on a storage oscilloscope (5111A; Tektronix Inc., Beaverton, OR). Analogue waveforms for voltage clamp command pulses and online data acquisition and analysis were accomplished with pClamp (Axon Instruments) using an $80-\mathrm{kHz}$ analoguedigital conversion board (Labmaster; Scientific Solutions, Tekmar, Co., Cleveland, $\mathrm{OH}$ ) and an AT personal computer (IBM Corp., Danbury, CT). Current traces elicited by voltage steps were filtered at a corner frequency of $3 \mathrm{kHz}$ by an 8-pole low-pass Bessel Filter (Frequency Devices, Inc., Haverhill, MA), digitized at $10 \mu \mathrm{s}-500-\mu \mathrm{s}$ intervals and stored in the microcomputer for later analysis.

Current time constants were determined by least-squares fitting of a two-exponential function to the current trace using pClamp. The curve fitting method used for the $I_{\mathrm{Ca}_{\mathrm{a}}}$ steady-state inactivation curve was based on the Marquardt-Levenberg algorithm for the least-squares fit to a nonlinear function. The fitting procedure was performed by a commercially available software program (SigmaPlot; Jandel Scientific, Corde Madera, CA).

Cell capacitance and series resistance. Cell capacitance was calculated from the capacitative transient produced by a 10-mV hyperpolarizing voltage clamp step from a holding potential $\left(V_{\mathrm{b}}\right)$ of $-40 \mathrm{mV}$. The cell capacitance $\left(c_{\mathrm{m}}\right)$ was defined as the ratio of the area under the current transient (total charge) photographed from the oscilloscope with Polaroid film using a Tektronix C-5 camera to the magnitude of the hyperpolarization step $(-10 \mathrm{mV})$. The area under the current transient was determined by digitizing the current transient using a digitizing pad (SummaSketch; Summagraphics Corp., Fairfield, CT) and SigmaScan software (Jandel Scientific). To determine the accuracy and resolution of our measurements of membrane capacitance, we applied the same technique to measure the membrane capacitance of a model cell. We used a model cell with a known capacitance of $30 \mathrm{pF}$ from Axon Instruments. By applying a voltage of $-50 \mathrm{mV}$ we obtained a capacitive current trace on the oscilloscope screen that was similar in size to capacitance currents obtained from CTRL and DXR rats. The total charge measured by our technique was within $98 \%$ of the predicted value for the model cell. For cells with a membrane capacitance of $150 \mathrm{pF}$ our method would allow us to measure capacitance to within $3 \mathrm{pF}$ of the actual value.

The time constant, tau, for the decay of the capacitance transient was determined by fitting the digitized data to a single exponential function, $y=A \exp (-t / t a u)$. After series resistance compensation the residual series resistance was reduced to $\sim 1 \mathrm{M} \Omega$ (average reduction of $75 \%$ ) (14). With a mean maximal calcium current of $1,300 \mathrm{pA}$ the maximal voltage drop across the uncompensated series resistance was small $(\sim 1.3 \mathrm{mV})$

Calcium antagonist receptor equilibrium binding assays. $\left[{ }^{3} \mathrm{H}\right]-$ PN200-110 (New England Nuclear, Boston, MA) was used to perform radioligand binding studies in heart membranes from six DXR and six CTRL rats essentially as described by Ehlert et al. (15). In brief, hearts were removed, weighed, minced, and homogenized in a Polytron homgenizer (Brinkmann Instruments Co., Westbury, NY), in ice cold 50 $\mathrm{mM}$ Tris- $\mathrm{HCl}$ at a pH of 7.4. The homogenate was centrifuged for 10 $\mathrm{min}$ at $1,000 \mathrm{~g}$. The supernatant was centrifuged at $34,000 \mathrm{~g}$ for $20 \mathrm{~min}$. The pellet was resuspended in Tris- $\mathrm{HCl}$ buffer and centrifuged at $34,000 \mathrm{~g}$ for another $20 \mathrm{~min}$. The washing was repeated twice. The final pellet was resuspended in Tris-HCl buffer for the binding assay.

For the binding reaction, each tube contained $100 \mu \mathrm{g}$ protein in a total vol of $2.0 \mathrm{ml}$. For saturation isotherms, concentrations varying from 0.25 to $1.0 \mathrm{mM}$ of $\left[{ }^{3} \mathrm{H}\right] \mathrm{PN} 200-110$ were used. $1 \mu \mathrm{M}$ nitrendipine was used to determine nonspecific binding. Incubations were carried out for $90 \mathrm{~min}$ at $25^{\circ} \mathrm{C}$. The samples were then filtered over GF-B glass fiber filters, using a Brandell Cell Harvester (Biomedical Research and Development Laboratories, Inc., Gaithersburg, MD). The filters were washed three times with $4 \mathrm{ml}$ of $50 \mathrm{mM}$ Tris buffer and placed in scintillation cocktail (Scintiverse II; Fischer Scientific Co., Pittsburgh, PA) and radioactivity extracted overnight before counting. Data were analyzed using the curve fitting program LIGAND (16). Protein was determined by the method of Lowry et al. (17).

Statistical significance was determined by either Student's $t$ test for unpaired data or analysis of variance. For factorial experiments, twoway analysis of variance (ANOVA) was used to test for a main effect at the 0.05 level of significance for factor cell type with two levels, CTRL and DXR. If a significant overall $F$ test on the main effect was found, a posteriori comparisons using the Newman-Keuls method were then made to determine differences in either the cell types and/or individual means at each level of membrane potential, $V_{m}(18)$. Data are presented as mean \pm SEM

\section{Results}

Effect of DXR treatment on the capacitative surface area. Complete characterization of the capacitative surface area and the L-type calcium channel with voltage-clamp experiments was performed in nine CTRL and nine DXR cells. The diameter and the length of the cells were determined at $\times 600$ using a fixed-stage inverted light microscope. The average length of the CTRL cells was $140 \pm 5 \mu \mathrm{m}$ and for the DXR cells it was $137 \pm 4$ $\mu \mathrm{m}$. The average width of the CTRL cells was $25 \pm 2 \mu \mathrm{m}$ and for the DXR cells it was $25 \pm 0.3 \mu \mathrm{m}$. The apparent cell surface areas, as calculated for a right circular cylinder, were $1.1 \pm 0.1$ and $1.1 \pm 0.03 \times 10^{-4} \mathrm{~cm}^{2}$ for the CTRL and the DXR cells, respectively. There were no significant differences $(P>0.05$, Student's unpaired $t$ test) in any of the cell dimensions between the CTRL and the DXR cells. 
Despite these similar cell dimensions the mean $c_{\mathrm{m}}$ for the DXR cells (138 \pm 9$)$ was significantly smaller than the value for the CTRL cells (169 $\pm 11 \mathrm{pF})$ (Fig. 1). Assuming a specific membrane capacitance of $1 \mu \mathrm{F} / \mathrm{cm}^{2}$ (19) for both the CTRL and the DXR cells, the capacitative surface area was $1.69 \pm 0.11$ $\times 10^{-4} \mathrm{~cm}^{2}$ for the CTRL cells and $1.38 \pm 0.09 \times 10^{-4} \mathrm{~cm}^{2}$ for the DXR cells $(P<0.05)$.

Isolation of $I_{C a}$. Fig. 2 shows that under the experimental conditions, the fast inward sodium current and the potassium currents (transient outward current, inward rectifying current, and the delayed outward current) were eliminated. After blockade of the L-type $\mathrm{Ca}^{2+}$ channel with $\mathrm{Cd}^{2+}$ only a time-independent background current remained.

Effects of DXR treatment on $I_{C a}$. Fig. 3 shows superimposed records of $I_{\mathrm{Ca}}$ in response to selected depolarization steps of 300 ms duration in a CTRL and a DXR cardiomyocyte. The amplitude of $I_{\mathrm{Ca}}$ was larger in the DXR cell than in the CTRL cell. The mean current-voltage relationship for nine CTRL and nine DXR cells is shown in Fig. 4 (upper panel) for comparison. The peak $I_{\mathrm{Ca}}$ was larger in the DXR cells than in the CTRL cells at membrane potentials of 10,20 , and $30 \mathrm{mV}$ (two-way ANOVA, $\mathrm{F}=10.0, P<0.01)$. There was no shift in the maximal peak current-voltage relationship with DXR cardiomyopathy. The maximum of the $I_{\mathrm{Ca}}$-voltage relationship was larger in the DXR cells $(1,302 \pm 200 \mathrm{pA})$ than in the CTRL cells $(1,037 \pm 134 \mathrm{pA})$. The difference in the current density-voltage relation for the CTRL and DXR cells was more apparent when the peak $I_{\mathrm{Ca}}$ was normalized to the corresponding cell capacitative surface area to obtain the current density, $(F=18.2, P$ $<0.001$ ) (Fig. 4, lower panel). The peak $I_{\mathrm{Ca}}$ density was significantly larger in the DXR cells $\left(10.5 \pm 2.4 \mu \mathrm{A} / \mathrm{cm}^{2}\right)$ than in the CTRL cells $\left(6.4 \pm 0.9 \mu \mathrm{A} / \mathrm{cm}^{2}\right)$ at membrane potentials of 0-40 mV.

To determine if the kinetics of inactivation of $I_{\mathrm{Ca}}$ were altered in DXR cardiomyopathy, the time course of the decay of $I_{\mathrm{Ca}}$ in response to clamp steps to the plateau range of the action potential was determined in the CTRL and the DXR cells using a least-squares fit to a two-exponential function of the form

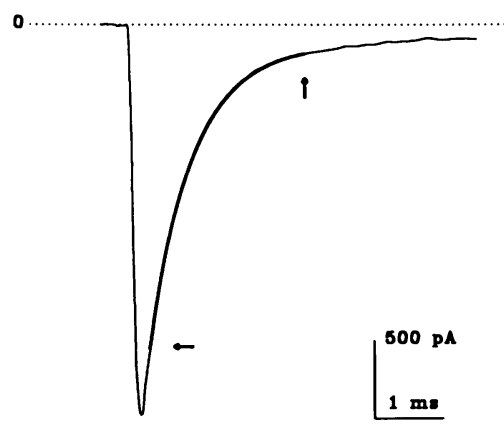

Figure 1. Digitized capacitive transients from a CTRL cell (upper panel) and a DXR cell (lower panel). The capacitance transients were elicited by a 10 $\mathrm{mV}$ hyperpolarization step from $V_{\mathrm{h}}=-40$ $\mathrm{mV}$. The decay of the capacitance transients was fitted by a single exponential function (represented by the superimposed curves) using least-squares fitting of the current traces between the two arrows. For the CTRL cell, tau $=0.7 \mathrm{~ms}$ and $c_{\mathrm{m}}=170$ $\mathrm{pF}$. For the DXR cell, tau $=0.6 \mathrm{~ms}$ and $c_{\mathrm{m}}$ $=132 \mathrm{pF}$.
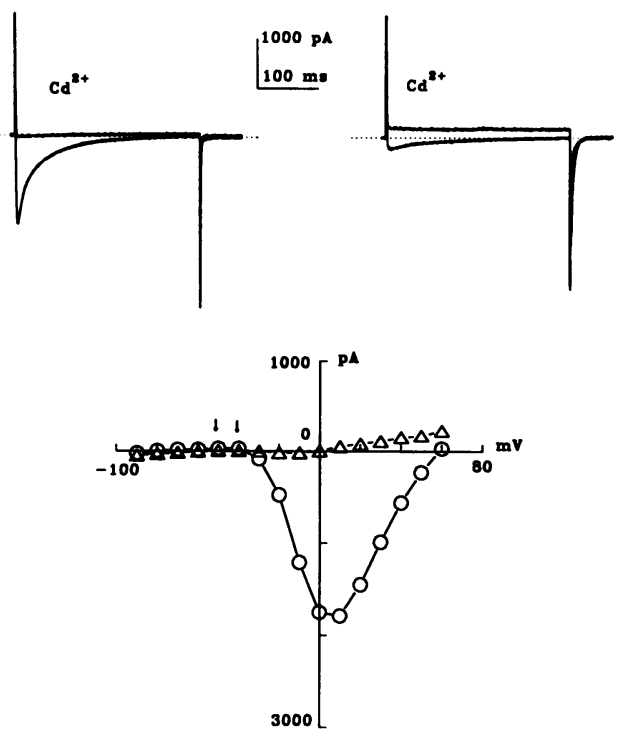

Figure 2. Isolation of the L-type calcium current $\left(I_{\mathrm{C}_{\mathrm{a}}}\right)$. Upper panels: $I_{\mathrm{Ca}}$ elicited by a depolarization step from a holding potential of -40 $\mathrm{mV}$ to a membrane potential of $0 \mathrm{mV}(l e f t)$ and $50 \mathrm{mV}$ (right) before and after addition of $2 \mathrm{mM} \mathrm{CdCl}{ }_{2}$ to the external solution. After blockade of $I_{\mathrm{Ca}}$ with $\mathrm{CdCl}_{2}$ only the time-independent background current remains. Lower panel: current-voltage relationship before (open circles) and after (open triangles) $\mathrm{CdCl}_{2}$ treatment. For $V_{\mathrm{m}}$ less negative than $-\mathbf{4 0} \mathrm{mV}$ open circles represent peak inward current. For $V_{\mathrm{m}}$ more negative than $-40 \mathrm{mV}$ open circles present current magnitude at $20 \mathrm{~ms}$ into the voltage step. $I_{\mathbf{K} 1}$ was completely eliminated under the experimental conditions. In this region (as indicated by arrows) the only contamination is a negligible background leak current. Dotted lines indicate zero current level.

\section{CTRL}

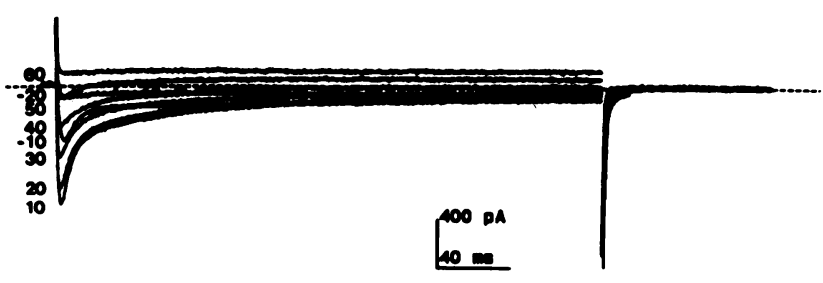

DXR

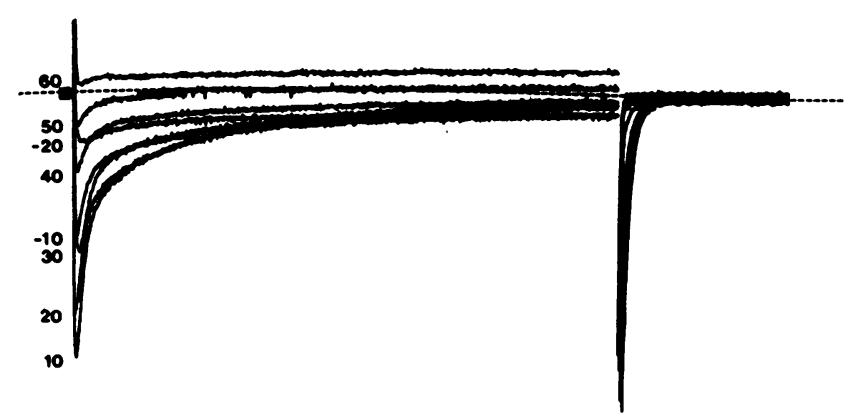

Figure 3. L-type calcium current $\left(I_{\mathrm{Ca}_{\mathrm{a}}}\right)$ records from a CTRL cell (upper panel) and a DXR-treated cell (lower panel) elicited by depolarization steps from a holding potential of $-40 \mathrm{mV}$ to membrane potentials indicated to the left of the current traces. Dotted lines indicate zero current level. 

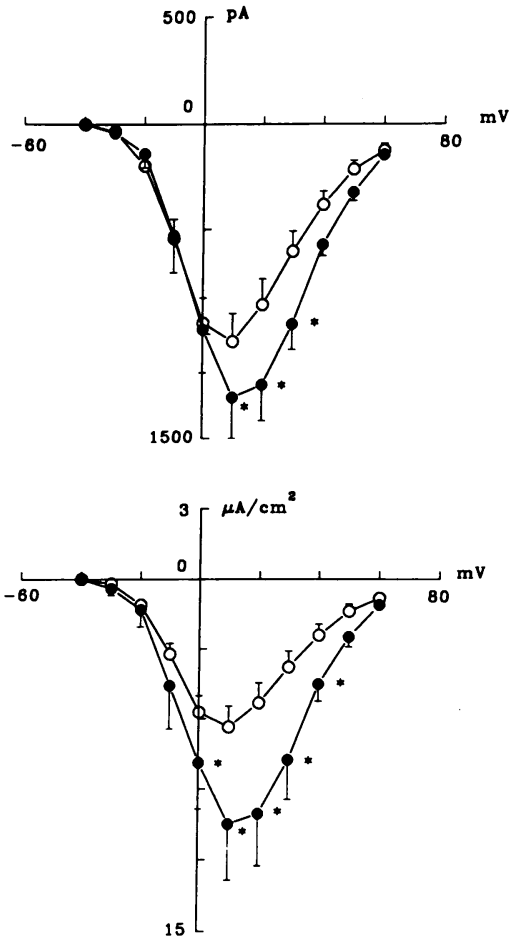

Figure 4. Upper panel: mean peak $I_{\mathrm{Ca}}$ current-voltage relationship for CTRL cells (open circles) and DXR cells ( filled circles). $I_{\mathrm{C}}$ was measured by the "visual estimate" method (41). Peak $I_{\mathrm{Ca}}$ was measured with respect to the current level at the end of the test pulse step (300 ms). Lower panel: peak $I_{\mathrm{Ca}}$ current density-voltage relationship obtained by normalization of the peak $I_{\mathrm{Ca}}$ to the corresponding capacitative surface area. $n=9$ for CTRL and DXR cells. Vertical error bars represent \pm SEM.

$A_{0}+A_{1} \exp \left(-t / \operatorname{tau}_{1}\right)+A_{2} \exp \left(-t / \operatorname{tau}_{2}\right)$. The fast time constant of inactivation, $t a u_{1}$, was longer in DXR than in CTRL cells at potentials between -10 and $10 \mathrm{mV}$ (two-way ANOVA, F $=8.11$ and $P<0.01$ ) (Fig. 5). On the other hand, the time constant for the slow component of inactivation was similar in the DXR and the CTRL cells $(\mathrm{F}=0.46$ and $P=0.50)$.

To compare further the voltage-dependent properties of $I_{\mathrm{Ca}}$ in CTRL and DXR cells the steady-state inactivation curve was determined in four CTRL and three DXR cells using a conventional two-pulse protocol. The inactivating prepulse was stepped from a $V_{\mathrm{h}}=-40 \mathrm{mV}$ to a membrane potential of $-70-0 \mathrm{mV}$ in 5-mV steps for $1 \mathrm{~s}$. The test pulse was stepped to $V_{\mathrm{m}}=0 \mathrm{mV}$ for $500 \mathrm{~ms}$. The current elicited by the test pulse was expressed as a fraction of the maximal current obtained when the test pulse was preceded by a prepulse hyperpolarized to $-70 \mathrm{mV}$. Fig. 6 shows the mean steady-state inactivation 1 variable, $f_{\infty}$, plotted against the inactivating prepulse potentials for CTRL and DXR cells. There was slight inactivation $\left(f_{\infty}=0.9\right.$ ) of calcium channels at $-40 \mathrm{mV}$ for both CTRL and DXR cells. The steady-state inactivation parameter, $f_{\infty}$, was represented by a Boltzmann distribution of the form $f_{\infty}=1 /\{1$ $\left.+\exp \left[\left(V-V_{0.5}\right) / b\right]\right\}$, where $f_{\infty}$ is the steady-state inactivation parameter, $V$ is the membrane potential, $V_{0.5}$ is the membrane potential at which $f_{\infty}=0.5$, that is, when half of the calcium channels are available for activation, and $b$, a constant, is the slope factor. There was no change in the availability of calcium channel for opening in DXR cells because the two inactivation curves were nearly identical. $V_{0.5}$ for the CTRL and the DXR cells were -30 and $-31 \mathrm{mV}$, respectively. $b$ for the CTRL and the DXR cells was 4.4 and 4.1 , respectively.

$\left[{ }^{3} \mathrm{H}\right] P N 200-110$ equilibrium binding assays. Calcium channel antagonist equilibrium binding studies were performed in six CTRL and six DXR rats. There were no significant differences in the maximal binding capacity, $B_{\max }$, between the CTRL (194 $\pm 27 \mathrm{fmol} / \mathrm{mg}$ protein) and the DXR $(211 \pm 24$

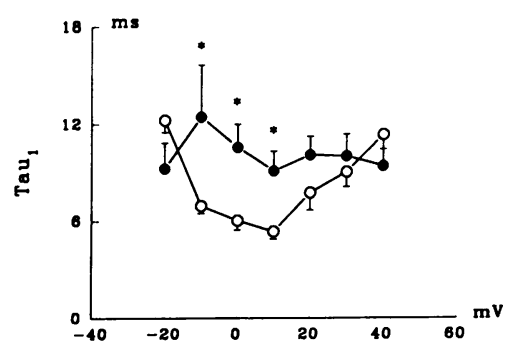

Figure 5. Time constants for inactivation

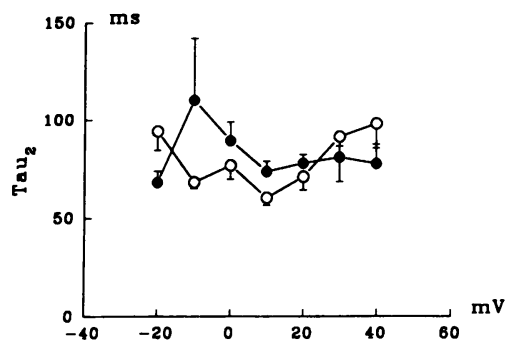
of $I_{\mathrm{Ca}}$ at different depolarization potentials in nine CTRL (open circles) and nine DXR ( filled circles) cells. Upper panel: mean fast time constant, $\operatorname{tau}_{1}$. Lower panel: mean slow time constant, $\operatorname{tau}_{2}$. Vertical error bars represent \pm SEM.

fmol/mg protein) heart membranes. The receptor binding affinity, $K_{\mathrm{d}}$, for the CTRL and the DXR heart membranes was $0.15 \pm 0.05$ and $0.13 \pm 0.03 \mathrm{nM}$, respectively $(P>0.05)$.

\section{Discussion}

Whole-cell voltage clamp. The whole-cell voltage clamp method using enzymatically isolated cardiomyocytes minimizes some of the major technical limitations inherent in voltage clamp studies on strands of atrial and ventricular muscles and Purkinje fibers. These limitations include inadequate voltage control in terms of time and space, nonuniformity of ionic concentration due to narrow intercellular space, and inability to control intracellular ionic and metabolic milieu (20). However, use of enzymatically isolated single ventricular cells may also introduce some unavoidable problems. The cell isolation process may have a sampling bias towards a subpopulation of cells in the normal hearts. In hearts from animal models that

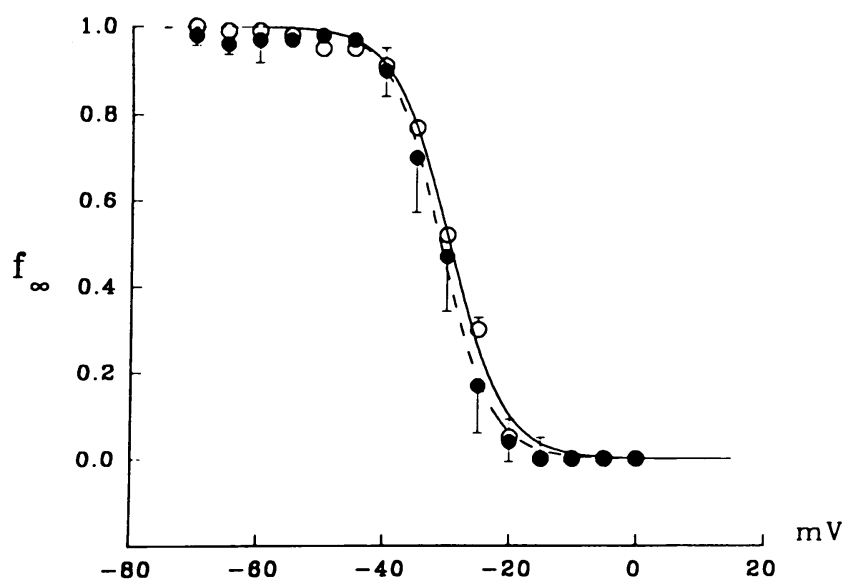

Figure 6. Steady-state inactivation of $I_{\mathrm{Ca}}$ in four CTRL (open circles) and three DXR (filled circles) cells. The mean data points were fitted by the Boltzmann distribution represented by $f_{\infty}=1 /\{1+\exp [V$ $\left.\left.\left.-V_{0.5}\right) / b\right]\right\}$ (CTRL, continuous curve; DXR, interrupted curve). Vertical error bars represent \pm SEM. 
mimic human pathophysiology, as in the DXR treated hearts, the surviving isolated cells may be part of a continuum of different cell types with different functional status and degree of morphologic changes in response to treatment. As in any voltage clamp studies using isolated single heart cells, our interpretation of the experimental data requires the assumption that the cardiomyocytes used in the experiments were representative of the cell population in the DXR hearts. With this limitation and assumption, alterations in membrane ionic channels have been demonstrated in various pathophysiologic animal models using the whole-cell voltage clamp method. For example, in renovascular hypertensive rats $I_{\mathrm{Ca}}$ is markedly increased and its time course of inactivation is prolonged (14). In cat heart subjected to pulmonary artery banding, the amplitude of $I_{\mathrm{Ca}}$ is unchanged but the time course of inactivation is also prolonged (21), whereas the delayed rectifier is reduced (22) and the ATP-regulated $\mathrm{K}$ channels are altered (23).

$D X R$ treatment and $I_{C a}$. The results of our whole-cell voltage clamp experiments showed that the peak $I_{\mathrm{Ca}}$ amplitude and the current density in response to clamp steps to the voltage levels of phase 2 and 3 of the action potential was modestly but significantly increased in DXR ventricular cardiomyocytes. Since there was no shift in the steady-state inactivation curve for the DXR cells, the increased $I_{\mathrm{Ca}}$ in DXR cells was not due to a change in the availability of calcium channels for activation in these cells. These findings are qualitatively similar to those reported for renovascular hypertensive rats. Unlike the latter, however, the fast time constant, instead of the slower time constant, of $I_{\mathrm{Ca}}$ inactivation was increased.

Our data demonstrate, for the first time, that $c_{\mathrm{m}}$ is significantly reduced in cardiomyocytes isolated from DXR rat hearts. Since $c_{\mathrm{m}}$ was determined in CTRL and DXR cells of similar length and width, this $18 \%$ reduction of the capacitative surface area (which was calculated assuming no change in the membrane specific capacitance, $1 \mu \mathrm{F} / \mathrm{cm}^{2}$ ) implies DXR causes a partial loss of the internal membranous system, most probably the t-tubular system. One characteristic electron micrographic finding in myocardium from humans and rats treated with DXR is vacuolization due to sarcotubular swelling $(2,7)$. Although a reduced $c_{\mathrm{m}}$ resulting from a change in the membrane dielectric constant remains a possibility, our finding strongly suggests that some of the t tubules in the DXR myocardium may have been functionally disconnected from the surface or physically destroyed. This novel observation provides an electrophysiologic correlation with the t-tubular damage observed in electron micrographs of myocardium from DXR rats.

"Detubulation" with concomitant reduction in the total capacitative area and swelling and disruption of the transverse tubular system has been observed in skeletal muscles treated with glycerol $(24,25)$. The most important consequence of detubulation in skeletal muscle is that the inward conduction pathway for electrical activity is interrupted resulting in loss of contraction (26). Although the role of the t-tubular system in cardiac muscle has not been well defined, there are reasons to believe that functional disconnection or physical destruction of the $t$ tubules in the DXR treated cells may, by itself, compromise excitation-contraction coupling if one assumes the presence of calcium channels in the cardiac $t$ tubules. In response to a stimulus, electrical activity would not be able to propagate down the swollen $t$ tubules in DXR myocardium, thus failing to activate the calcium channels that would otherwise act as passageway for activator calcium ions to trigger contraction. Physical disruption of the t-tubular system may result in the destruction of calcium channel architecture in the $t$-tubular system and render them nonfunctional.

Calcium channel antagonist receptor binding sites. The effects of various pathophysiologic alterations on calcium channel antagonist binding are variable and controversial. $B_{\max }$ and $K_{d}$ have been shown to be increased (27) and unchanged (28) in spontaneously hypertensive rats. Similarly, contradictory results of receptor binding assays have been reported in the cardiomyopathic Syrian hamster (28-31). In renovascular hypertensive rats (32) and in ischemic rat hearts (33) $B_{\max }$ has been shown to be decreased. In these studies, there have been no examination on any functional correlation between the number of calcium channels as measured by calcium antagonist binding, properties of the calcium channels, and cellular ultrastructural alterations.

Our equilibrium binding assays revealed no statistical difference in the maximal number of dihydropyridine binding sites and in the binding affinity $\left(K_{d}\right)$ between CTRL and DXR rat hearts. $B_{\max }$ (in fmol/mg protein) and $K_{\mathrm{d}}$ for the CTRL rat hearts measured in our study were similar to previously reported values $(28,33-36)$. The fact that antagonist binding capacity was unaltered in DXR hearts is of considerable interest in view of the increase in $I_{\mathrm{Ca}}$ and functional and/or physical disruption of the t-tubular membrane system.

By assuming one antagonist receptor binding site for each L-type calcium channel, the total number of calcium channels per cell, $N_{\mathrm{Ca}}$, can be estimated as follows: $N_{\mathrm{Ca}}=\left(B_{\max } / N_{\text {cell }}\right)$ $\times A$, where $N_{\text {cell }}=44 \times 10^{4}$ cells $/ \mathrm{mg}$ protein (34) (assuming a ratio of 10 for wet wt to protein; and that there was no cell loss in the DXR hearts) and $A$ is the Avagadro number $\left(6.02 \times 10^{23}\right.$ molecules $/ \mathrm{mol}$ ). Accordingly, we estimate that there are 27 $\times 10^{4}$ and $29 \times 10^{4}$ binding sites (or putative calcium channels) per CTRL and DXR cell, respectively. If myocardial cell loss occurred with DXR treatment, $N_{\mathrm{Ca}}$ would be $>29 \times 10^{4} / \mathrm{cell}$. If the $t$ tubules were partially destroyed, the functional consequence would be that a smaller number of calcium channels in the $t$-tubular membrane would be available for activation in response to a voltage step. To account for the putative compensatory increase in $I_{\mathrm{Ca}}$, either the properties of the activated channels are altered and/or otherwise "hibernating" channels in the surface or the remaining t-tubular membrane have been recruited. In view of the fact that the calcium channel density as estimated by $B_{\max }$ is uniformly several-fold larger than the number of electrically active channels determined by single channel recordings (37), there appears to be an abundance of hibernating channels in reserve, a notion that is akin to the concept of "spare" receptors.

$I_{C a}$ in excitation-contraction coupling. Results from several voltage clamp studies suggest a close relationship between the L-type calcium current and contractility in ventricular muscles $(38,39)$. Transmembrane influx of calcium ions via $I_{\mathrm{Ca}}$ plays a key role in the process of calcium-triggered release of calcium from the sarcoplasmic reticulum (40). The finding of an increase in $I_{\mathrm{Ca}}$ and $I_{\mathrm{Ca}}$ density in DXR cells in the presence of DXR-induced cardiomyopathy is intriguing. Damage to the sarcotubules and sarcoplasmic reticulum and loss of myofibrils in myocardium from DXR-treated rat suggest defects in the excitation-contraction coupling mechanism. To compensate 
for a partial loss of the t-tubular system, more functional calcium channels might have to be recruited from channels in hibernation with or without a concomitant increase in the individual channel properties.

\section{Acknowledgments}

We are very grateful to Robert Berg for his technical assistance and to Dr. Joel Karliner for his editorial comments.

E. C. Keung was supported by the Department of Veterans Affairs, Research Service, Washington, DC. The work was supported by a grant from the National Heart, Lung and Blood Institute (HL-28464 to R. A. Jensen).

\section{References}

1. Calabresi, P., and R. E. Parks, Jr. 1985. Antiproliferative agents and drugs used for immunosuppression. In The Pharmacological Basis of Therapeutics. A. G. Gilman, L. S. Goodman, T. W. Rail, and F. Murad, editors. Macmillan Publishing Co., New York. Chap. 55.

2. Singal, P. K., C. M. R. Deally, and L. E. Weinberg. 1987. Subcellular effects of adriamycin in the heart: a concise review. J. Mol. Cell. Cardiol. 15:817-828.

3. Holmberg, S. R. M., P. A. Poole-Wilson, and A. J. Williams. 1989. Interactions of doxorubicin and mitoxantrone with the calcium release channel from cardiac sarcoplasmic reticulum. Circulation. 80:II-141. (Abstr.)

4. Abramson, J. J., E. Buck, G. Salama, J. E., Casida, and I. N. Pessah. 1988 Mechanism of anthraquinone-induced calcium release from skeletal muscle sarcoplasmic reticulum. J. Biol. Chem. 263:18750-18758.

5. Jensen, R. A. 1986. Doxorubicin cardiotoxicity: contractile changes following long term treatment in the rat. J. Pharmacol. Exp. Ther. 236:197-203.

6. Jensen, R. A., E. M. Acton, and J. H. Peters. 1984. Doxorubicin cardiotoxicity in the rat: comparison of electrocardiogram, transmembrane potential, and structural effects. J. Cardiovasc. Pharmacol. 6:186-200.

7. Jensen, R. A., E. M. Acton, and J. H. Peters. 1984. Electrocardiographic and transmembrane potential effects of 5-iminodaunorubicin in the rat. Cancer Res. 44:4030-4039.

8. Silver, L. H., E. L. Hemwell, T. A. Marino, and S. R. Houser. 1983. Isolation and morphology of calcium tolerant feline ventricular cardiomyocytes. Am. J. Physiol. 245:H891-896.

9. Isenberg, G., and U. Klöckner. 1982. Calcium tolerance ventricular cardiomyocytes prepared by preincubation in a "KB medium." Pfluegers Arch. Eur. J. Physiol. 395:6-18.

10. Hamill, O. P., A. Marty, M. E. Neher, B. Sakmann, and F. J. Sigworth. 1981. Improved patch-clamp techniques for high-resolution current recording from cells and cell-free membrane patches. Pfluegers Arch. Eur. J. Physiol. 391:85-100.

11. Lee, K. S., J. R. Hume, W. Giles, and A. M. Brown. 1981. Sodium current depression by lidocaine and quinidine in isolated ventricular cells. Nature (Lond.). 291:325-327.

12. Matsuda, H., and A. Noma. 1984. Isolation of calcium current and its sensitivity to nonvalent cations in dialyzed ventricular cells of guinea-pig. J. Physiol. (Lond.). 357:553-573.

13. Josephson, I. R., J. Sanchez-Chapula, and A. M. Brown. 1984. Early outward current in rat single ventricular cells. Circ. Res. 54:157-162.

14. Keung, E. C. 1989. Calcium current is increased in isolated adult cardiomyocytes from hypertrophied rat myocardium. Circ. Res. 64:753-763.

15. Ehlert, F. J., W. R. Roeske, E. Itoga, and H. I. Yamamura. 1982. The binding of $\left[{ }^{3} \mathrm{H}\right]$ nitrendipine to receptors to calcium channel antagonist in the heart, cerebral cortex, and ileum of rats. Life Sci. 30:2191-2202.

16. Munson, P. J., and D. Rodbard. 1980. LIGAND: a versatile computerized approach for characterization of ligand binding systems. Anal. Biochem. 107:220-239.

17. Lowry, O. H. N. J. Rosenbrough, A. L. Farr, and R. J. Randall. 1961. Protein measurement with the Folin phenol reagent. J. Biol. Chem. 193:265-275.

18. Winer, J. 1971. Statistical Principles in Experimental Design, McGrawHill, New York. Chap. 6.
19. Cole, K. S. 1968. Membrane, Ions and Impulses. University of California Press, Berkeley. p. 12.

20. Hagiwara, S., and L. Byerly. 1981. Calcium channel. Ann. Rev. Neurosci. 4:69-125.

21. Kleiman, R. B., and S. R. Houser. 1988. Calcium currents in normal and hypertrophied isolated feline ventricular myocytes. Am. J. Physiol. 255:H1434 1442.

22. Kleiman, R. B., and S. R. Houser. 1989. Outward currents in normal and hypertrophied feline ventricular myocytes. Am. J. Physiol. 256:H1450-1461.

23. Cameron, J. S., S. Kimura, D. A. Jackson-Burns, D. B. Smith, and A. L. Bassett. 1988. ATP-sensitive $\mathrm{K}^{+}$channels are altered in hypertrophied ventricular myocytes. Am. J. Physiol. 255:H1254-1258.

24. Howell, J. N. and D. J. Jenden. 1967. T-tubules of skeletal muscle: morphological alterations which interrupt excitation-contraction coupling. Fed. Proc. 26:553 (Abstr.)

25. Gage, P. E., and R. S. Eisenberg. 1969. Capacitance of the surface and transverse tubular membrane of frog sartorius muscle fibers. J. Gen. Physiol. 53:298-310.

26. Howell, J. N. 1969. A lesion of the transverse tubules of skeletal muscle. J. Gen. Physiol. 201:515-533.

27. Chatelain, P., D. Demol, and J. Roba. 1983. Comparison of $\left[{ }^{3} \mathrm{H}\right]$ nitrendipine binding to heart membranes of normatensive and spontaneously hypertensive rats. J. Cardiovasc. Pharmacol. 6:220-223.

28. Dillon, J. S., X. H. Gu, and W. G. Nayler. 1989. Effect of age and of hypertrophy on cardiac $\mathrm{Ca}^{2+}$ antagonist binding sites. J. Cardiovasc. Pharmacol. 14:233-240.

29. Wagner, J. A., I. J. Reynolds, H. F. Weisman, P. Dudeck, M. L. Weisfeldt, and S. H. Snyder. 1986. Calcium antagonist receptors in cardiomyopathic hamster: selective increases in heart, muscle, brain. Science (Wash. DC). 232:515518 .

30. Finkel, M. S., E. S. Marks, R. E. Patterson, E. H. Speir, K. A. Steadman, and H. R. Keiser. 1987. Correlation of changes in cardiac calcium channels with hemodynamics in Syrian hamster cardiomyopathy and heart failure. Life Sci. 41:153-159.

31. Howlett, S. E., V. F. Rafuse, and T. Gordon. 1988. $\left[{ }^{3} \mathrm{H}\right]-$-nitrendipine binding sites in normal and cardiomyopathic hamster: absence of a selective increase in putative calcium channels in cardiomyopathic hearts. Cardiovasc. Res. 22:840-846.

32. Andrawis, N. S., T. H. Kuo, F. Giacomelli, and J. Wiener. 1988. Altered calcium regulation in the cardiac plasma membrane in experimental renal hypertension. J. Mol. Cell. Cardiol. 20:625-634.

33. Nayler, W. G., J. S. Dillon, J. S. Elz, and M. McKelvie. 1985. An effect of ischemia on myocardial dihydropyridine binding sites. Eur. J. Pharmacol. 115:81-89.

34. Green, F. J., B. B. Farmer, G. L. Wiseman, M. J. L. Jose, and A. M. Watanabe. 1985. Effect of membrane depolarization on binding of $\left[{ }^{3} \mathrm{H}\right]$ nitrendipine to rat cardiac myocytes. Circ. Res. 56:576-585.

35. Rogart, R. B., A. DeBruyn Kops, and V. J. Dzau. 1986. Identification of two calcium channel receptor sites for $\left[{ }^{3} \mathrm{H}\right]$ nitrendipine in mammalian cardiac and smooth muscle membrane. Proc. Natl. Acad. Sci. USA. 83:7452-7456.

36. Mayoux, E. F., F. Callens-El Amrani, and B. Swynghedauw. 1988. Adaptational process of the cardiac $\mathrm{Ca}^{2+}$ channels to pressure overload: biochemical and physiologic properties of the dihydropyridine receptors in normal and hypertrophied rat hearts. J. Cardiovasc. Pharmacol. 12:390-396.

37. McDonald, T. F. A. Cavalie, W. Trautwein and D. Pelzer. 1986. Voltagedependent properties of macroscopic and elementary calcium channel currents in guinea pig ventricular myocytes. Pflueger Arch. Eur. J. Physiol. 406:437-448.

38. Trautwein, W., R. F. McDonald, and O. Tripathi. 1975. Calcium conductance and tension in mammalian ventricular muscle. Pflueger Arch. Eur. J. Physiol. 354:55-74.

39. Gibbons, W. R. 1986. Cellular control of cardiac contractility. In The Heart and Cardiovascular System. H. A. Fozzard, E. Haber, R. B. Jennings, A. Katz, and H. E. Morgan, editors. Raven Press, Inc., New York. Chap. 36.

40. Fabiato, A. 1983. Calcium-induced release of calcium from the cardiac sarcoplasmic reticulum. Am. J. Physiol. 245:C1-14.

41. Isenberg, G., and U. Klockner. 1982. Calcium currents of isolated bovine ventricular myocytes are fast and of large amplitude. Pflueger Arch. Eur. J. Physiol. $395: 30-41$. 